\title{
Dominance of honey bees is negatively associated with wild bee diversity in commercial apple orchards regardless of management practices
} \author{
Peter Vandamme $^{\mathrm{f}}$, Nicolas J. Vereecken ${ }^{\mathrm{a}}$

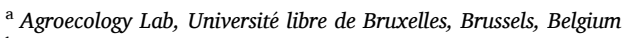 \\ ${ }^{\mathrm{b}}$ Laboratory of Zoology, Université de Mons, Mons, Belgium \\ ${ }^{\mathrm{c}}$ Division of Forest, Nature and Landscape, University of Leuven, Leuven, Belgium \\ ${ }^{\mathrm{d}}$ School of Agriculture, Policy and Development, University of Reading, Reading, United Kingdom \\ e Department of Plants and Crops, Ghent University, Ghent, Belgium \\ ${ }^{\mathrm{f}}$ Department of Biochemistry and Microbiology, Ghent University, Ghent, Belgium
}

Timothy Weekers ${ }^{\mathrm{a}, *}$, Leon Marshall ${ }^{\mathrm{a}}$, Nicolas Leclercq ${ }^{\mathrm{a}}$, Thomas James Wood ${ }^{\mathrm{b}}$, Diego Cejas ${ }^{\mathrm{b}}$, Bianca Drepper ${ }^{\mathrm{c}}$, Louise Hutchinson ${ }^{\mathrm{d}}$, Denis Michez ${ }^{\mathrm{b}}$, Jean-Marc Molenberg ${ }^{\mathrm{a}}$, Guy Smagghe ${ }^{\mathrm{e}}$,

\section{A R T I C L E I N F O}

\section{Keywords:}

Pollinator

Organic

Diversity

Agroecology

Conservation

Management

\begin{abstract}
A B S T R A C T
Commercial apple production relies on managed honey bees (Apis mellifera) for pollination, and on intensive management for pest control. Previous studies have highlighted the potentially detrimental effects of intensive crop management on wild bee diversity in agroecosystems, potentially jeopardizing the pollination services they provide. However, the extent to which honey bee dominance and crop management interact under field-realistic conditions and drive the structure of wild bee assemblages has not been investigated so far. In this study, we measured species richness, as well as the functional and phylogenetic diversity of wild bee assemblages in 36 paired organic and non-organic apple orchards during their flowering season and along a geographic gradient across western Europe. Our results show a strong significant and negative association between honey bee dominance and all wild bee diversity metrics, regardless of local management. Semi-natural habitats had a significant and positive effect on functional diversity, while urbanization and crop cover around the orchards showed no effect on all measured diversity metrics. A greater number of species exhibited less common, or frequent, combinations of functional traits at sites with high honey bee dominance, especially larger bee species with longer tongues. Collectively, we show that wild bee diversity decreases with increasing honey bee dominance, and that this negative association is not buffered by alternative (i.e., organic) management practices in commercial apple orchards. Although organic farming can bring about biodiversity benefits, our study demonstrates that, in the context of commercial apple production, other measures are needed to enhance and harness biodiversity for sustainable and profitable crop production. In particular, a lowered reliance on honey bees and a redesign of orchards through configurational crop heterogeneity and/or the restoration of in-field semi-natural elements are required beyond agricultural input substitution.
\end{abstract}

\section{Introduction}

Insect pollinators play a pivotal role in the sexual reproduction of wild flowering plants, as well as in the production of fruits and seeds for an estimated $75 \%$ of global crop species (Klein et al., 2007; Ollerton et al., 2011). The importance of insect pollination as an (agro-) ecosystem service is currently on the rise, as the global area dedicated to pollinator-dependent crops has increased by more than 300\% since 1961 (Aizen et al., 2008). For example, apple (Malus domestica) is now one of the most economically important fruit crops in the world, with an estimated economic value over $\$ 45$ billion for the year 2019 (FAOSTAT, 2020). Wherever they are currently cultivated, apple crops generally

\footnotetext{
* Correspondence to: Agroecology Lab, Université libre de Bruxelles (ULB), Campus de la Plaine (CP 264/2), 1050 Brussels, Belgium.

E-mail addresses: Timothy.Weekers@ulb.be (T. Weekers), Leon.Marshall@ulb.be (L. Marshall), Nicolas.Leclercq@ulb.be (N. Leclercq), ThomasJames.WOOD@

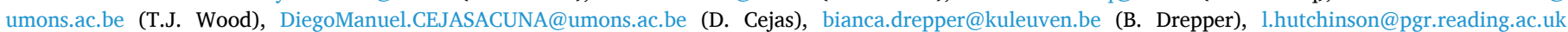

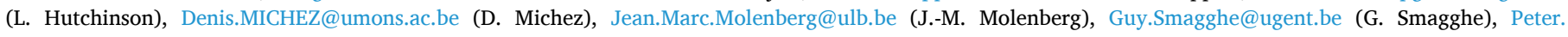
Vandamme@ugent.be (P. Vandamme), Nicolas.Vereecken@ulb.be (N.J. Vereecken).
} 
rely on insect pollinators such as bees and hoverflies for their sexual reproduction, since they are usually self-incompatible (Pardo and Borges, 2020). Apple blossoms typically attract a wide taxonomic range of pollinators (Nunes-Silva et al., 2020) and different suites of pollinator species in different biogeographic regions of the world (Prendergast et al., 2021; Ramírez and Davenport, 2013), yet producers around the world have converged towards a significant reliance on managed colonies of the Western honey bee Apis mellifera L. for apple pollination (Garibaldi et al., 2013). This tight functional link between apples in particular, and a considerable proportion of our crops more generally (Bänsch et al., 2020) and this single pollinator species in regions with available suites of non-managed pollinator species (contra Prendergast et al., 2021) is increasingly viewed as a non-resilient strategy in the context of global change. Indeed, a major stress affecting the beekeeping sector in this context has the potential to jeopardize the availability of managed hives to support the pollination demand of apples and other crops, and therefore threaten both crop production and food security (Potts et al., 2010).

Because honey bees alone are not responsible for the production of pollinator-dependent crops (Breeze et al., 2011), the contribution of alternative managed pollinators and the encouragement of wild pollinators are being increasingly explored (Blitzer et al., 2016; Pérez-Méndez et al., 2020). These initiatives have been supported by reports that wild pollinators, and especially wild bees, significantly contribute to crop pollination, and often out-perform honey bees in terms of pollination efficiency at the individual level (Garibaldi et al., 2013). Furthermore, there is now mounting evidence that the diversity of bees, in particular their species richness but also their functional diversity (i.e., the diversity of ecological and behavioral traits exhibited by pollinator species), and phylogenetic community structure are important drivers of ecosystem services (Grab et al., 2019; Hoehn et al., 2008). Crop pollination and fruit set (a key component when considering crop yield) are affected, with enhanced productivity and improved stability for different types of pollinator-dependent crops (Grab et al., 2019; Hoehn et al., 2008; Pérez-Méndez et al., 2020).

One important factor that limits the increased use of wild pollinators to sustain crop pollination services is that many of these species are currently facing multiple threats (Wagner, 2020) which need to be overcome to reduce their associated pollination deficits (Garibaldi et al., 2016). Apart from environmental stressors such as climate change and land-use change, agricultural intensification has placed increased pressure on wild bee communities (Nieto et al., 2014). As such, organic agriculture has been proposed as a sustainable alternative to conventional farming practices, since it involves growing and nurturing crops without the use of synthetic based fertilizers and pesticides, ultimately increasing species richness and abundance of wild pollinators in some contexts (Rundlöf et al., 2016). According to Hill's (1985) transition theory, the degree of sustainability attained in a transition away from resource-and energy efficient ("E") conventional farming practices and its associated environmental benefits largely depends on the extent to which the agroecosystem undergoes a substitution ("S") of conventional agricultural inputs by non-synthetic inputs complying with the organic standards and regulations, and finally a redesign (R) of the production management approaches through sustainable and ecology-friendly approaches (Pretty, 2020).

Despite the popular trend in considering honey bees as important allies in crop pollination and as "umbrella" species for the conservation of all pollinators (Wood et al., 2020), recent evidence suggests that honey bees can impact local pollinator populations by competing for resources, especially in floral hotspots (Hung et al., 2019). For example, Ropars et al. (2020) found a significant and negative association between increased honey bee colony density and the diversity and community structure of wild bees in urban green spaces, but similar results and concerns are echoed by studies in semi-natural and agricultural contexts (Lindström et al., 2016; Mallinger et al., 2017). Dominant bee species (i.e., those that are highly represented within a community) such as honey bees can therefore have a considerable influence on the overall dynamics of pollinators communities, species richness and plant-pollinator interactions (Graystock et al., 2020; Hillebrand et al., 2008).

In the context of (i) an increased consumer interest in organically grown apples in recent years (Willer et al., 2021), (ii) the reported benefits of organic agriculture on biodiversity (Rundlöf et al., 2016), but also (iii) the prevalent use of A. mellifera as a managed pollinator for apple production, we aimed to disentangle the associations between honey bee dominance, management practices (organic vs. non-organic), and wild bee diversity in commercial apple orchards. Contrary to previous studies focusing on either of these stressors for wild bees separately, predominantly using mostly artificial experimental setups (Brittain et al., 2013; Campbell et al., 2017), and focusing on relatively small geographical scales (Grab et al., 2019; Porcel et al., 2018), we designed a large-scale study with an explicit focus on management by using a paired commercial apple orchards approach (i.e., organic and non-organic). Specifically, we used standardized field surveys to investigate how much (i) the dominance of $A$. mellifera and (ii) contrasting farming management interact and influence the diversity of wild bees (computed through species richness, functional and phylogenetic diversity metrics) associated with apples in different climatic contexts of Western Europe. We hypothesize that high dominance of honey bee will be associated with lower wild bee diversity indices, and that this impact will be weaker in organically managed sites. Our results are discussed in light of Hill's (1985) Efficiency-Substitution-Redesign theory, and we then provide evidence-based recommendations to commercial apple growers and policymakers (Pardo and Borges, 2020) to promote agroecological practices that would combine the conservation of farmland biodiversity with agricultural and economic objectives.

\section{Material and methods}

\subsection{Study area and sampling method}

During the 2019 apple blooming season, we sampled 36 commercial apple orchards (hereafter referred to as "sites") in Belgium, France, the Netherlands, Spain and the United Kingdom (Fig. 1; see Fig. S1, Table S1 in Supporting Information). All sites were managed either according to guidelines and requirements of organic farming practices (hereafter referred to as "organic") or according to other practices such as integrated pest management (IPM) or conventional agriculture (hereafter referred to as "non-organic"). All non-organic sites observed similar management intensity, and were therefore grouped into a single category (Orpet et al., 2020). The sites were grouped into closely located pairs of organic and non-organic orchards, never further apart than 15 $\mathrm{km}$. Within each pair, the sites were separated by at least $2 \mathrm{~km}$ to avoid the potential overlapping of pollinator assemblages (Gathmann and Tscharntke, 2002; Zurbuchen et al., 2010). This pair strategy allowed to focus on sites with different management practice, yet located in close and similar landscapes, and experiencing comparable climatic conditions. Each site was sampled for three consecutive days during the peak blooming period, using a standardized protocol combining active (netting) and passive (pan traps) collection methods (Droege et al., 2010). Active sampling from apple blossoms allowed surveying the bee community directly associated with the crop, starting at a random point and then following the orchard lanes during two periods of $90 \mathrm{~min}$. The passive sampling was deployed on cleared ground using trios of painted pan traps (fluorescent blue, fluorescent yellow, white), (i.e., nine pan traps in total with three pan traps of each color, set for the day and collected late afternoon) filled with soapy water (Westphal et al., 2008). Complementarily to active sampling, the passive sampling allowed to survey bee species present in and around the apple orchards, indirectly associated with the crop. The recollection of a more complete community of wild bees at the orchard level can be of use regarding biodiversity study, with implications to crop production (Nicholls and Altieri, 2013; 


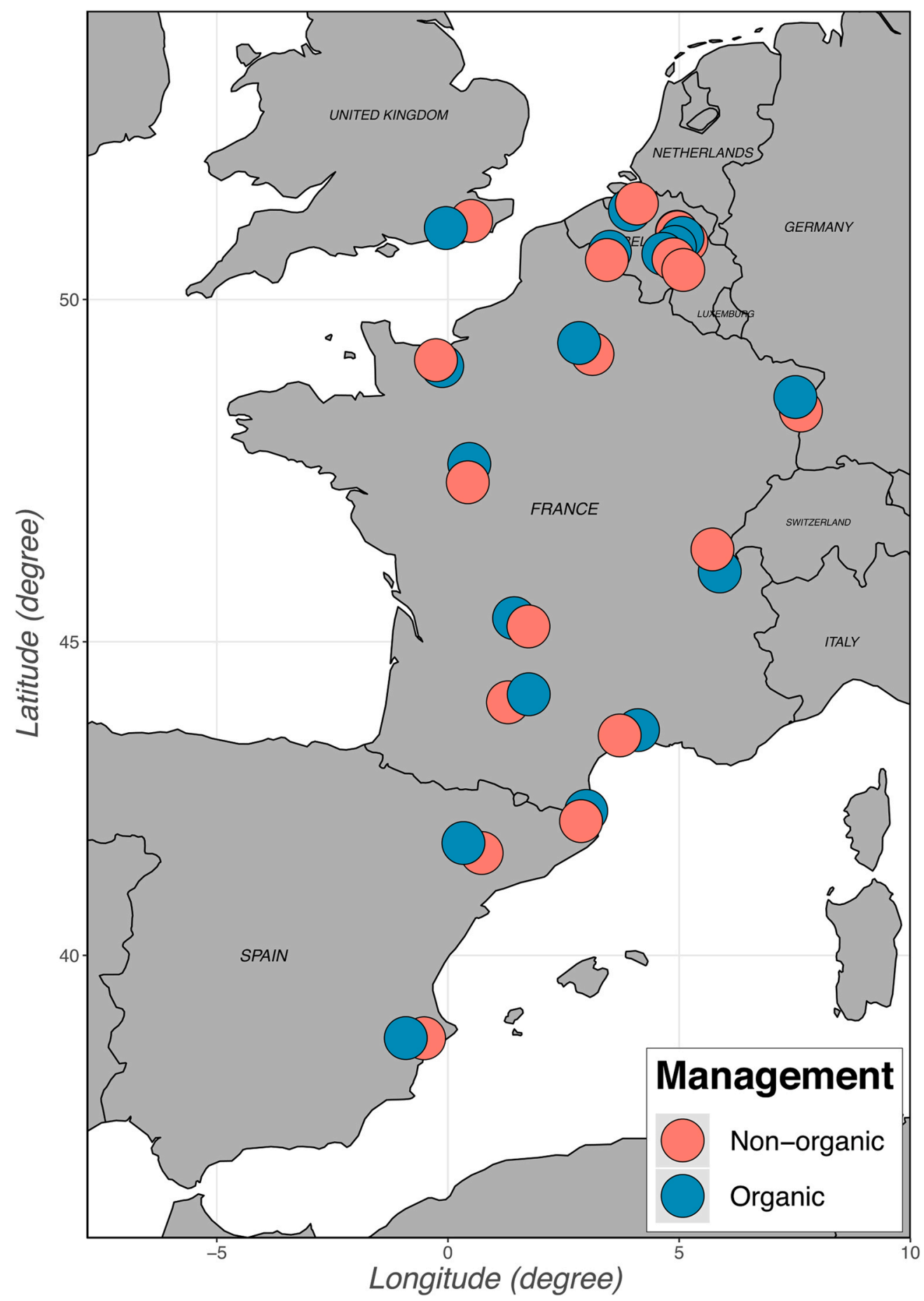

Fig. 1. Map of the 36 apple orchards sampled, organized in pairs (each with organic non-organic site). Each site is represented by a colored circle, corresponding to the management system observed. See Fig. S1 for detailed sites of Belgium.

Tscharntke et al., 2021). Only bee samples were considered in this study. All collected specimens were identified to the species level and their entry digitized, except for Bombus terrestris and B. lucorum which were pooled together as "Bombus terrestris agg." (Table S2 for species list). All specimens are curated in the entomological collection of the Agroecology Lab (Université libre de Bruxelles (ULB), Brussels, Belgium).

\subsection{Diversity indices}

For all our analyses, we pooled the data collected using both methods of trapping. The active and passive sampling methods used are complementary in terms of the species caught, and are most efficient when used in combination to study richness and diversity (Droege et al., 2010; Nielsen et al., 2011) (see Fig. S2). We then characterized the entire bee community using the metrics species richness (SR), functional diversity (FD) and phylogenetic diversity (PD). These diversity metrics have been previously used as proxies to assess community characteristics, and are also relevant to measure the provisioning of ecosystem services (Woodcock et al., 2019). Species richness is the simple computation of the number of different species observed in each site. In our analyses, we used individual-based rarefied species richness, allowing meaningful standardization among study sites and comparison 
of management systems (hereafter referred to as "SR") (Gotelli and Colwell, 2001). The functional diversity of a community represents the diversity of life-history traits of bees within each community (Normandin et al., 2017). For all species recorded, we gathered the following traits using the literature (Carreck, 2016; Potts et al., 2015), and confirmed by experts: nesting type, sociality, body size (or inter-tegular distance), tongue length, pollen transport, season of flight, diet breadth (Table S3). Tongue length (in $\mathrm{mm}$ ) was computed from the inter-tegular distance (ITD) of sampled female specimens using the ITconverter function of the "BeeIT" package (version 0.1.0) (Cariveau et al., 2016). The final traits matrix was used to build a "functional dendrogram" illustrating the similarity in life-history traits among species, with the hclust function from the "stats" package (version 4.1.0) (R Core Team, 2013), and the gowdis function from the "FD" package (version 1.0-12) (Laliberté et al., 2015). We then computed FD as the total branch length of this functional dendrogram representing each bee community (Petchey and Gaston, 2007). We computed the FD value of bee communities associated with each study site using the alpha function of the "BAT" package (version 2.0.1) (Cardoso et al., 2015) (Table S4). We also selected PD as an alternative biodiversity metric, as species traits do not always reflect shared evolutionary history (i.e., there are multiple cases of life-history traits convergence in the European bee fauna, see (Vereecken, 2017; Vereecken et al., 2020). In this context, we built a phylogeny (Appendix S1) based on fragments from the mitochondrial cytochrome oxidase I (COI) and low-wavelength opsin ( $\mathrm{LW} \mathrm{Rh}$ ) genes, hereafter referred to as multi-gene (Boyle and Adamowicz, 2015) (Fig. S3; Table S5). We computed PD based on the multi-gene tree (and also on the taxonomic tree for comparison, see Guala and Döring, 2021) by summing the lengths of connecting species found in each community of bees, an appropriate measure of the evolutionary history shared among species forming a community (Grab et al., 2019). Values of PD for each site were computed using the alpha function from the "BAT" package (version 2.0.1) (Table S4).

We also calculated the dominance of honey bees, as the proportion of honey bees caught (in \%) in each site. Dominance was chosen to account for the relative "weight" of honey bees in the overall community, rather than the total abundance (varying greatly between days of sampling, whereas dominance proved more stable over time) (Fig. S4). After comparing honey bee dominance with honey bee hives presence in each site and for each method of trapping (Fig. S5), we also decided to use the amount of honey bee hives set up in each apple orchard to account for introduced honey bee populations (Table S1).

\subsection{Landscape analyses}

To include potential effects of landscape features on our data (Marini et al., 2012), we computed Shannon's landscape diversity index (Shdi) for every study site, at the $500 \mathrm{~m}, 1000 \mathrm{~m}, 1500 \mathrm{~m}$ and $2000 \mathrm{~m}$ radius, based on 23 different land cover classifications from the 2019 Copernicus Global Land Cover (100 m $\times 100 \mathrm{~m}$ resolution) (Buchhorn et al., 2020 ) and using the calculate_lsm function from the "landscapemetrics" package (version 1.5.2) (Hesselbarth et al., 2019) (Table S6). The highest correlations between Shdi and the diversity metrics was obtained at the $1000 \mathrm{~m}$ buffer radius (Table S7) (Radzevičiūte et al., 2021), which was then used to extract the relative proportion of three landscape features: agriculture cover, urbanization and semi-natural habitats (Grab et al., 2019; Raderschall et al., 2021; Theodorou et al., 2020). This was done using the geobuffer_pts function from the "geobuffer" package (version 0.0.0.90) (Stefan, 2019), using the same Copernicus Global Land Cover (Table S6). In each site, we also measured the following local metrics: grass height, size of the orchard, wildflower abundance, wildflower diversity, and the orchard's age. There were no overall differences between organic and non-organic sites for the tests made, and no significant effect on any of the three, diversity metrics (Table S8). Therefore, these orchard measurements were not used in the final analyses.

\subsection{Statistical analyses}

To investigate the patterns of honey bee dominance (in \% of the local community) in relation to the biodiversity (SR, FD and PD) of wild bees, we used generalized linear mixed models (GLMMs) with the three, diversity metrics as response variables. For SR as the response variable, we computed a generalized linear mixed regression model with a Poisson error distribution, using the glmer function from the "lme4" package (version 1.1-23) (Bates et al., 2015). FD and PD (taxonomic and Multi trees) were modeled with a gaussian error distribution, using the lmer function of the "Ime4" package (version 1.1-23) (Bates et al., 2015). In all models, the following predictor variables were used: agriculture cover $(1 \mathrm{~km})$, urbanization cover $(1 \mathrm{~km})$, semi-natural habitats cover $(1 \mathrm{~km})$, management (organic versus non-organic), honey bee dominance, number of honey bee hives, the interaction between honey bee dominance and the management, and the interaction between honey bee dominance and the number of bee hives.

Spatial autocorrelation between sites was tested using the fitme function of the "spaMM" package (version 3.4.1) (Rousset and Ferdy, 2014), and was accounted by using the site pair number as random effect (Fig. S6). To avoid potential sampling biases, we also computed the sampler's identity as random effect (Roulston et al., 2007). The random effects were removed from the SR model, as they explained no variance, resulting in singular fits. Pearson's correlation coefficient were used to test for significant correlations between the different predictor variables (Birkhofer et al., 2018) (Table S9), and none were found. We also tested for correlations among the diversity metrics (see Results). All appropriate model assumptions were checked.

\subsection{Functional space analysis}

After exploring what predictors influenced most the diversity metrics, we investigated more specifically how the distribution of functional traits in wild bee communities changed with increasing dominance of honey bees. Following the theoretical framework of Mouillot et al. (2013), we used the traits matrix previously computed to obtain $x, y$ coordinates for each species sampled in a functional space, using the pcoa function of the "ape" package (version 5.4) (Paradis and Schliep, 2019).

From the total community, we extracted two distinct and contrasting groups, each with roughly a similar number of specimens (details in the Results section). The first group encompassed the bee species sampled from all the sites with a honey bee dominance below $27 \%$ (hereafter referred to as "Low Apis sites"), while the second group comprised the species from all sites above $50 \%$ of honey bee dominance (hereafter referred to as "High Apis sites"). The bee species caught in the remaining sites (i.e., with a honey bee dominance between $27 \%$ and $50 \%$ ) were referred to as "Medium Apis sites". This classification allowed to compare clusters of sites with distinct and contrasting levels of honey bee dominance (Fig. S7). Hence, the following analyses have been computed after removing honey bees from the dataset. For each group, the remaining bee species were then placed in a two-dimensional plot using Principal Coordinate Analysis (PCoA) axes, forming visually contrasting convex hulls in the functional space and illustrating the trait distribution within each group.

We characterized these convex hulls using four metrics, all derived from the first general FD used above, and more suited when describing the portion of the functional traits space occupied by certain communities (Mouchet et al., 2010): functional richness (FRic, i.e. portion of functional space filled by species communities), functional evenness (FEve, i.e. distribution of abundance among species in the functional space), functional divergence (FDiv, i.e. relative abundance of species with extreme functional traits), and functional specialization (FSpe, i.e. differing contribution to the functional space from generalist species and species with extreme trait combinations). Finally, we tested which functional traits were significantly contributing to the changes observed 
in the functional spaces with a binomial ANOVA, using the Anova function of the "car" package (version 3.0-10) (Fox and Weisberg, 2014).

\section{Results}

\subsection{Patterns of diversity in commercial apple orchards}

A total of 10,513 bees were caught in the 36 sites sampled during the 2019 flowering period (Table S2). They consisted of 151 species from five different families (Andrenidae, Apidae, Colletidae, Halictidae, and Megachilidae) (Table S10). Apis mellifera represented $40.55 \%$ of the total abundance in our database, with 4263 specimens caught across all sites; its dominance ranged between $9.25 \%$ and $87.50 \%$ of sampled specimens per site (Fig. S7). The next most abundant species in our dataset were Bombus terrestris agg. (1294 specimens), Lasioglossum

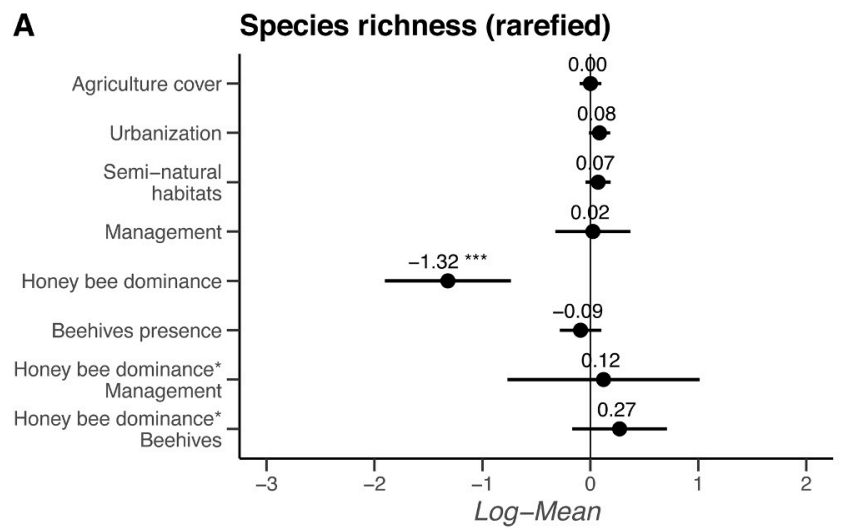

C

Functional diversity

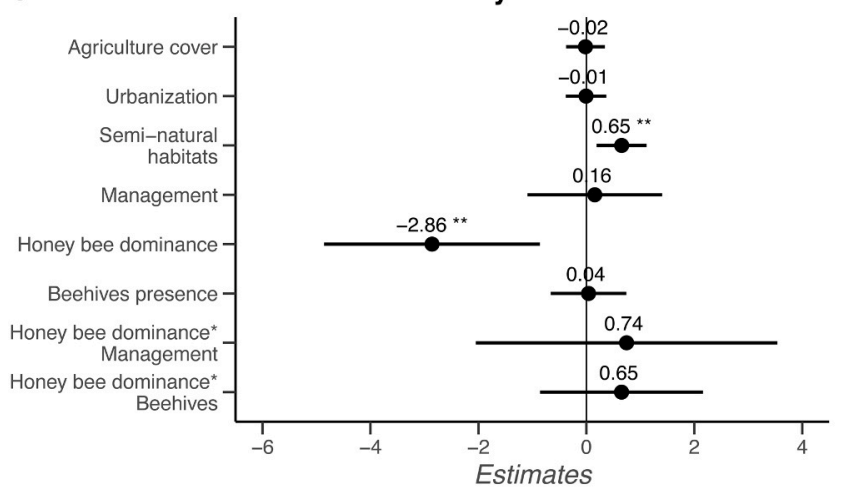

E

Phylogenetic diversity (Multi)

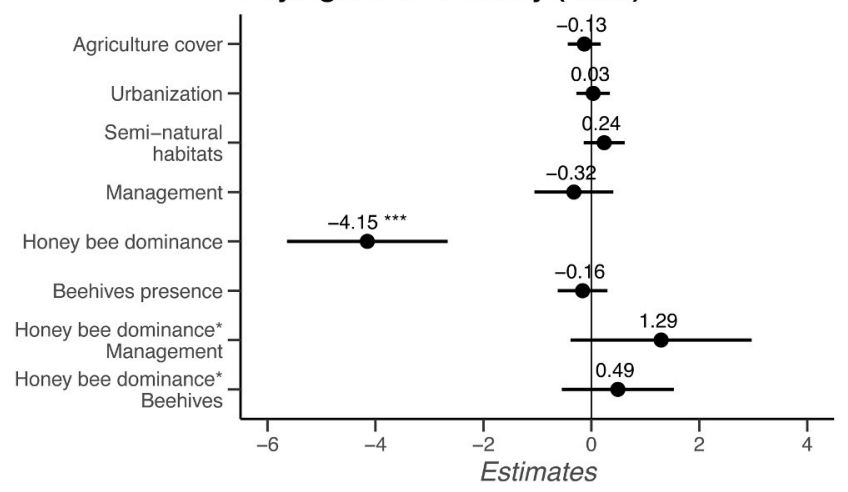

malachurum (594), Andrena haemorrhoa (377), Osmia bicornis (273), and A. flavipes (242).

\subsection{Effect of honey bee dominance and management on wild bee diversity}

Our results indicated a strong and significant correlation between all diversity metrics (response variables). Looking at pairwise correlations, we see Pearson's correlation coefficients of 0.81 for SR-FD ( $P=1.49 \mathrm{e}-$ 09), 0.91 for SR-Multi PD (P $<2.65 \mathrm{e}-14), 0.71$ for FD-Multi PD $(\mathrm{P}=1.19 \mathrm{e}-6)$, and 0.97 for Taxonomic PD-Multi PD $(\mathrm{P}<2.2 \mathrm{e}-16)$. With these correlations, we showed hereafter that honey bee dominance is significantly and negatively associated with all tested variables, although the magnitude of the effect varied (Fig. 2).

We found a highly significant and negative association between honey bee dominance on the SR of wild bees in the studied sites, with an estimate of -1.32 (conditional $\mathrm{R}^{2}=0.824$, CI $95 \%=[-1.91,-0.74]$,

\section{B}

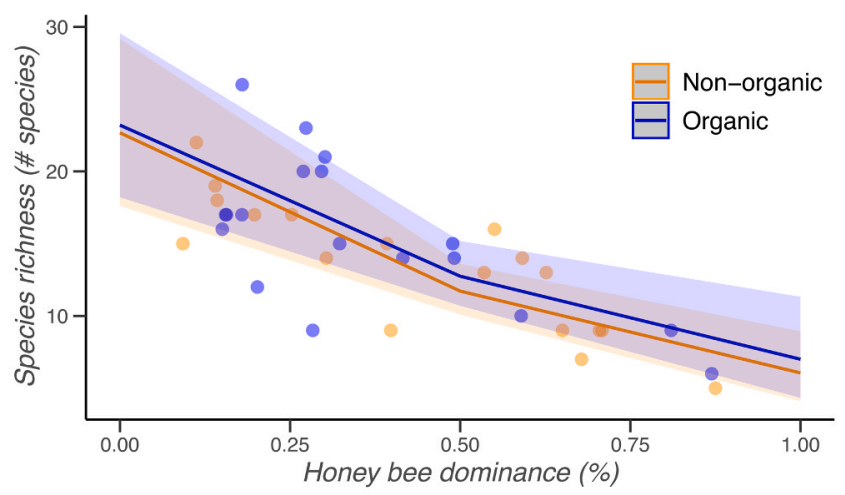

D

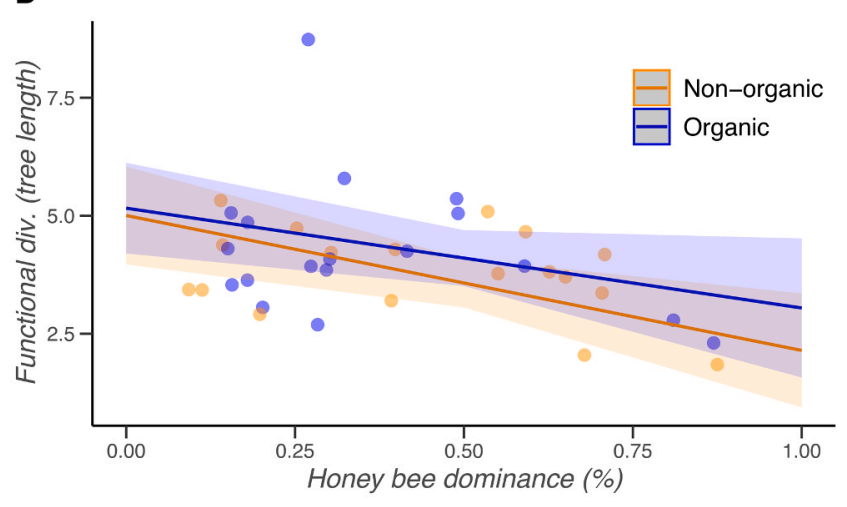

$\mathbf{F}$

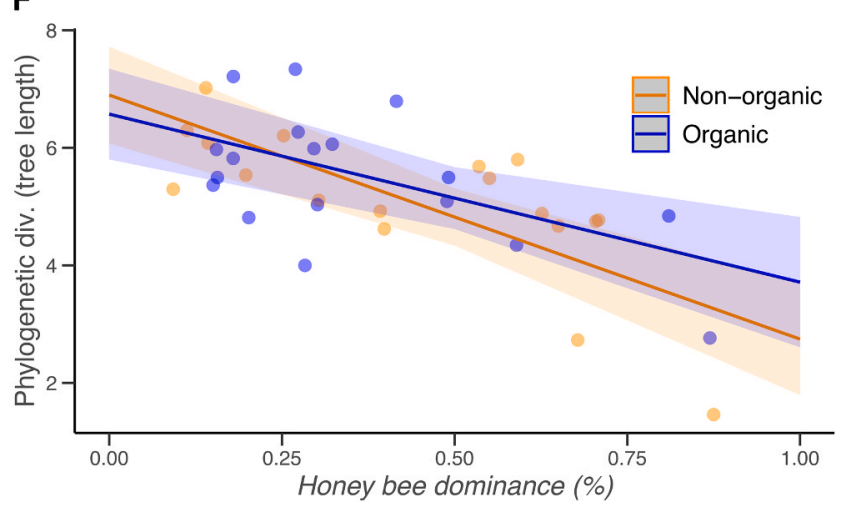

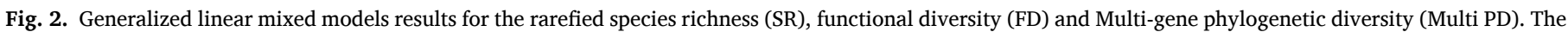

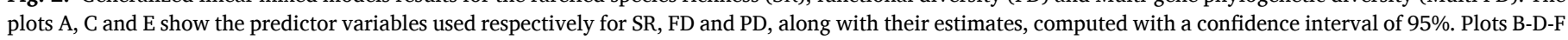

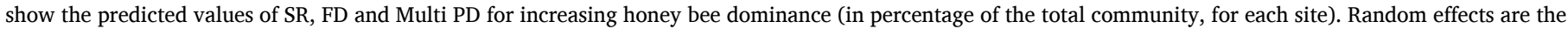
sampler's identity and site pair. 
$\mathrm{P}<0.001$ ) (Fig. 2A, B; Table S11). The estimate (in log-mean) converted into an incidence rate ratio (IRR $=0.27$ ) indicated that for every 20 -percentage point increase in honey bee dominance, there was a predicted decrease of $14.6 \%$ in wild bee SR. Secondly, our results indicated that honey bee dominance is also highly significant and negatively correlated with FD, with an estimate of -2.88 (conditional $\mathrm{R}^{2}=0.54$, (CI $95 \%=$ $[-4.87,-0.89], \mathrm{P}=0.005$ ) (Fig. 2C, D; Table S11). For every 20-percentage point increase in honey bee dominance, our model indicated a decrease by 0.58 of the total branch length of the tree linking all species in a community (Petchey and Gaston, 2006). The mean functional diversity among all sites was equal to 4.04 , hence for every 20 -percentage point increase in honey bee dominance, we would expect to lose $14.24 \%$ of FD in the communities. Semi-natural habitat had a significant and positive effect on FD, with an estimate of 0.6 (CI 95\% $=[0.16,1.05]$, $\mathrm{P}=0.008$ ), with higher natural habitat cover being associated with higher predicted FD (Fig. 3). Finally, the mixed linear regression for PD (multi-gene tree) also shows a highly significant and negative correlation with honey bee dominance (estimate $=-4.12$, conditional $\mathrm{R}^{2}=$ 0.85 , CI $95 \%=[-5.56,-2.68], \mathrm{P}<0.001$ ) (Fig. 2E, F; Table S11). According to our model, a decrease by $15.61 \%$ of the total branch length of the phylogenetic tree can be expected for every 20 -percentage point increase in honey bee dominance. Similar results were obtained for the Linnean taxonomic phylogeny (Table S12). All interactions tested in the models were non-significant (Table S11). Management (organic vs. non-organic) did not play a significant role in any of our analyses.

\subsection{Functional community space}

Roughly a third of the total specimen abundance (3832 specimens on 10,513 total) was found in Low Apis sites, a third (2907) in Medium Apis sites, and the last third (3774) in High Apis sites. After removing honey bees, the five following bee families were found in both Low and High Apis sites: Apidae (respectively $33.22 \%$ and $43.19 \%$ of abundance), Andrenidae (38.35\% VS 37.43\%), Halictidae (21.93\% VS $11.15 \%$ ) Megachilidae (6.25\% VS $8.01 \%$ ), and Colletidae (0.26\% VS $0.22 \%$ ) (Fig. S8).

To illustrate changes in the structure of wild bee communities between Low and High Apis sites, all species were positioned spatially by coordinates from Axis 1 [12.69\% of variance], Axis 2 [10.72\% of variance] and Axis 3 [7.96\% of variance] of the PCoA. The resulting twodimensional functional space from the Low Apis sites is visually larger than the High Apis sites (Fig. 4). We computed values of FRiC, FEve, FDiv and FSpe for each group, and tested the differences between both groups (Table 1). FSpe increased from 0.30 to 0.39 between the Low and High Apis sites, with mean SR going from 30.23 to 17.08 (and abundance changing from 3119 to 1336 specimens caught, after removing honey bees). Except for FSpe ( $P=0.003$ ), the other metrics (mean FRic, mean FEve and mean FDiv) were not significantly different between the two groups of sites, and were therefore not considered as relevant.

The functional traits significantly changing between species in Low and High Apis sites were the body size (ITD), the nesting habit and the diet breadth (Table S13). Overall, large bees showing diet preferences and/or nesting in existing cavities, made up a greater proportion of the bees found in High Apis sites. For example, visits by species like B. sylvestris (cuckoo bee), Anthophora aestivalis (polylectic with a strong preference for Fabaceae), Eucera nigrescens (oligolectic on Fabaceae), A. bicolorata and A. tenuistriata (both oligolectic on Brassicaceae) are motivated primarily by the collection of nectar. Species with an ITD (body size) over $4 \mathrm{~mm}$ tended to be more represented in High Apis sites (37.5\%) compared to Low Apis sites (27.48\%). Bees nesting in existing cavities increased with honey bee dominance (43.04\% vs 27.89 ), while ground nesting species decreased ( $54.57 \%$ vs $67.65 \%)$. Finally, species with a certain diet preference (i.e., for one plant genus) occurred more frequently in High Apis sites (10.48\%) than in Low Apis sites (2.12\%). (Fig. S9 for the remaining traits).

\section{Discussion}

\subsection{Diversity patterns}

Contrary to theoretical expectations, our results show for the first time in 36 apple orchards and at an unprecedented geographic scale across western Europe that organic management is not associated with increased wild bee diversity. By contrast, we found that the dominance of honey bees was consistently associated with lower wild bee richness, functional diversity and phylogenetic diversity, irrespective of the local management strategies. Overall, the landscape structure had very little impact on our results (contra Ropars et al., 2020) except for the positive influence of semi-natural habitats on functional diversity (Joshi et al., 2016; Odanaka and Rehan, 2019). We also observed a small but significant increase in the functional specialization of wild bee functional space when honey bee dominance was higher, suggesting that some species with extreme combinations of ecological and behavioral traits are more represented under conditions of high honey bee dominance

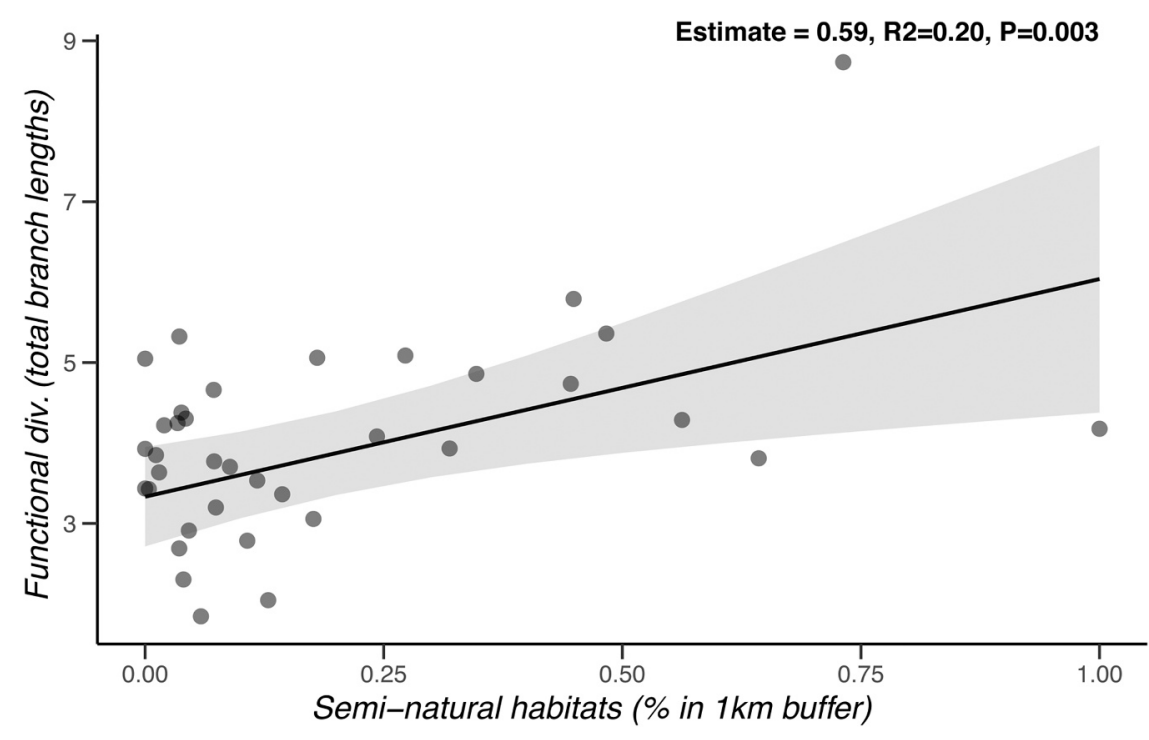

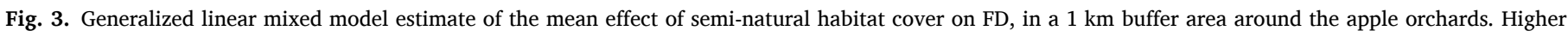
natural covers result in higher FD on average. 

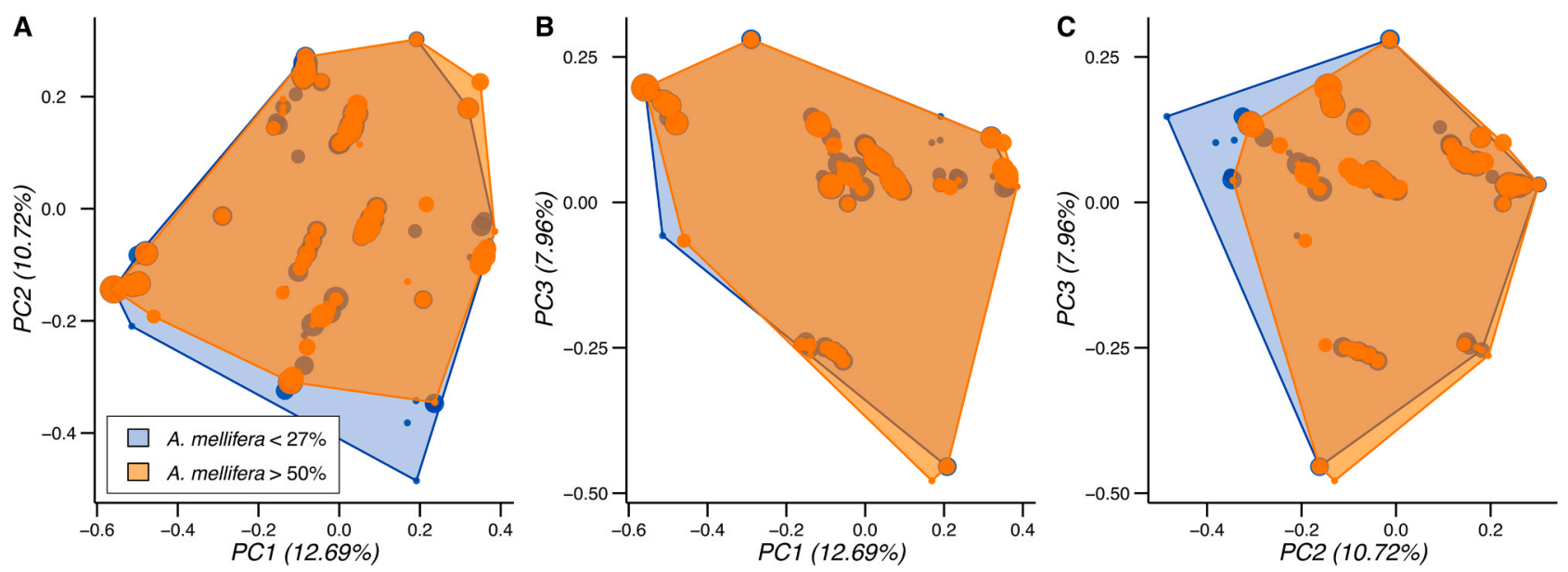

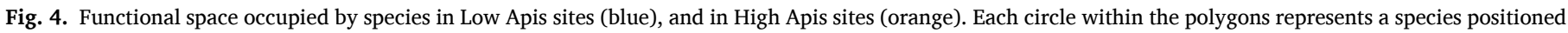

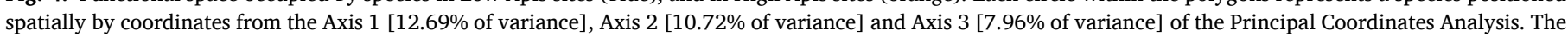

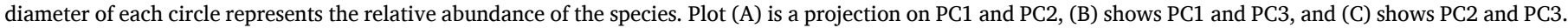

Table 1

The following functional diversity metrics, derived from the more general FD index, were used to characterize the functional space computed from High and Low Apis sites: functional richness (FRic), functional evenness (FEve), functional divergence (FDiv), and functional specialization (FSpe). The only metrics showing a significant difference between both groups is FSpe $(P=0.003)$, suggesting that specialist species (in terms of behavioral and ecological traits) are more represented in High Apis sites.

\begin{tabular}{lcllll}
\hline & Species richness & FRic & FEve & FDiv & FSpe \\
\hline Low Apis sites & 30.2308 & 0.0510 & 0.3268 & 0.8023 & 0.2982 \\
High Apis sites & 17.0833 & 0.0346 & 0.3501 & 0.8154 & 0.3944 \\
T.test p-value & 0.0022 & 0.1786 & 0.3345 & 0.7363 & $\mathbf{0 . 0 0 3}$ \\
\hline
\end{tabular}

(Geslin et al., 2017; Ropars et al., 2019). In particular, we found that the occurrence of larger bees which specialize on non-Rosaceae plant families for the collection of pollen and/or which visit apple blossoms exclusively for the collection of nectar was more frequent at sites with high honey bee dominance.

\subsection{Specialization under high honey bee dominance}

Large pollinators (such as Bombus or Eucera species) with similar morphologies and tongue lengths tend towards seeking similar floral resources, generally foraging preferentially on deep flowers (Fontaine et al., 2005; Rodríguez-Gironés and Santamaría, 2006). In contrast to such morphologically complex flowers, apple flowers show an open structure that allows many bee species to access floral nectaries, either by coming in contact with the anthers or bypassing them at the side of the flower (base of the anthers) (Krishna and Keasar, 2018; Sheffield et al., 2016). Potentially high competition resulting from high honey bee dominance on apple blossoms may therefore differentially affect short-tongued, generalized, and smaller-bodied solitary bees which often forage on shallow flowers due to their shorter mouthparts (corrected for body size) (Geslin et al., 2013; Ropars et al., 2019). In this regard, bees specialized on non-Rosaceae resources may be less impacted by high honey bee dominance, a potential explanation of the patterns observed in this study (Ropars et al., 2019; Wignall et al., 2020). However, there is still a lack of studies investigating the impact of honey bees on wild bee species with different foraging and nesting habits (Wojcik et al., 2018), most studies having focused on exploitative competition with bumblebees (Wignall et al., 2020).

\subsection{Management effect on wild bee assemblages}

The absence of any management effect on our results is unexpected, since organic agriculture has previously been shown to increase species richness and abundance of wild pollinators (Holzschuh et al., 2008; contra Porcel et al., 2018). Considering that apple production is highly dependent on pest management to succeed (Simon et al., 2011), our results therefore suggest that conventional and organic management in the commercial orchards studied strongly overlap in production expectations, soil quality and pest management strategies (Orpet et al., 2020; contra Reganold et al., 2001). In line with Hill's (1985) ESR theory for a transition toward more sustainable agroecosystems, we expected organic farming in commercial apple orchards to have undergone a redesign ("R") phase, e.g. through configurational crop heterogeneity and/or the restoration of in-field semi-natural elements (Alignier et al., 2020; Isbell et al., 2017) beyond the substitution ("S") phase. However, our personal observations in situ during the field surveys and our results suggest that organic management practices in apple orchards appear to have largely stagnated at the substitution $(E+S)$ stage, without implementing a real redesign strategy (Joshi et al., 2020). Although organic pesticides are expected to be less harmful to insects than synthetic pesticides used in conventional orchards, the volume and concentrations of spraying are often comparable or even higher, resulting in similar effects on overall insect populations (Orpet et al., 2020). As suggested by Orpet et al. (2020), conventional and organic practices can be highly heterogenous, implementing practices from either integrated practices, or by observing management recommendations to different degrees (Marliac et al., 2015; Merfield et al., 2015). The distinction between organic and non-organic management practices can thus be sometimes rather blurry, particularly when based primarily on agricultural input substitution, making tactics and recommendations to enhance sustainability and biodiversity applicable in either cases (Orpet et al., 2020; Shennan et al., 2017). Instead of focusing preferentially on certifications and labels, enhanced sustainability in apple orchards can and should be achieved by observing a mix of strategies better suited to local conditions (Kirchmann et al., 2016; Merfield et al., 2015; Orpet et al., 2020; Shennan et al., 2017).

\subsection{Potential influence of honey bee dominance}

Although our experimental design does not allow to formally identify the factor of factors driving the observed patterns of wild bee diversity, we hypothesize that they might be the direct outcome of honey bee dominance levels at the local scale, a phenomenon consistent with 
results of recent studies conducted in different habitats (urban: Ropars et al., 2019; Prendergast and Ollerton, 2021; semi-natural: Ropars et al., 2020; agricultural: Lindström et al., 2016; Mallinger et al., 2017). Indeed, neither the management strategy nor the landscape structure, two major drivers of changes in patterns of biodiversity, had a significant impact on the patterns of wild bee diversity, suggesting that another key factor may be at play. Therefore, we suggest that honey bee dominance might be responsible for the biodiversity patterns observed (Mallinger et al., 2017; Ropars et al., 2019; Valido et al., 2019). As we observed during our study, apple growers seem to follow a prevalent and strict reliance upon honey bees as "agricultural insurance" associated with high densities of honey bees (Park et al., 2020), whose negative impacts on biodiversity have been reported elsewhere in a variety of habitat types, including in agroecosystems (Geslin et al., 2017). In cases where wild bee diversity is crucial to pollination success, as in apple production, high number of honey bees will not likely improve pollination, and could even weaken that service (Blitzer et al., 2016; Garibaldi et al., 2013). In particular, even with high abundances of managed honey bees around, a loss in phylogenetic and functional diversity of bee communities can result in weakened crop yields and overall fruit quality (Blitzer et al., 2016; Grab et al., 2019; Martins et al., 2015). Whilst complete reliance on wild pollinators for large scale agriculture may be challenging because of their inter-annual demographic variation (Normandin et al., 2017), unpredictability, and vulnerability (Rader et al., 2009), a strong dependence on honey bees is also potentially commercially risky, should their numbers plummet following unpredictable events such as unfavorable temperatures, novel diseases, or parasites (Hristov et al., 2020), or simply the commercial unavailability of honey bee hives independent of these factors.

\section{Conclusion}

In light of our results and the abovementioned considerations, we argue that more experimental research should seek to confirm our conclusions and investigate how a reduction of honey bee populations in apple orchards (and thus a lowered reliance on them by growers) could benefit wild bee populations in terms of diversity and functionality, thereby strengthening the ecosystem services they provide. Future studies should include potential confounding effects not measured here, such as latitude or longitude, altitude, local floral resources, landscape context, thinning practices and blossom density, among others (Arnold et al., 2021; Martins et al., 2015; McKerchar et al., 2020). Furthermore, our results advocate for the need to redesign apple orchards and management practices, beyond agricultural input substitution (Joshi et al., 2020; Penvern et al., 2012). As honey bees and wild bees have different foraging patterns within apple orchards, future conservation and management measures should focus on enhancing species richness and diversity of bee species, allowing in return improved pollination efficiency and resulting crop yields (Alignier et al., 2020; Mallinger and Gratton, 2015). To ensure a sustainable and profitable crop production (Park et al., 2020), producers should therefore favor agroecological practices that actively support diverse and functional pollinator communities (Penvern et al., 2019; Ropars et al., 2020), and known to contribute to on-farm pollinator conservation (Forrest et al., 2015; Mateos-Fierro et al., 2021; Nicholls and Altieri, 2013).

\section{Funding}

The F.R.S.-FNRS and FWO joint program "EOS - Excellence of Science" (Belgium) for the project "CliPS: Climate change and its effects on Pollination Services (project 30947854)" funded and made it possible to elaborate this study.

\section{CRediT authorship contribution statement}

DM, GS, PV and NJV. TWeekers, LM, NL, TWood, DC, BD, LH, DM, JMM and NJV collected the data. TWood, LH, DM, and NJV identified specimens. DC sequenced specimens and built the phylogenetic tree. TWeekers analyzed the data. TWeekers, LM, NL and NJV led the writing of the manuscript. All authors have read and agreed to the submitted version of the manuscript.

\section{Declaration of Competing Interest}

The authors declare that they have no known competing financial interests or personal relationships that could have appeared to influence the work reported in this paper.

\section{Data availability statement}

Should the manuscript be accepted, the data supporting the results will be archived in an appropriate public repository (Dryad, Figshare or Hal) and the data DOI will be included at the end of the article.

\section{Acknowledgements}

The F.R.S.-FNRS and FWO joint program "EOS - Excellence of Science" (Belgium) for the project "CliPS: Climate change and its effects on Pollination Services (project 30947854)" funded and made it possible to elaborate this study. Thanks to the apple growers who allowed access to their land and shared their knowledge. Thanks to A.Pauly, A.Dorchin and S.Roberts and D.De Grave for providing species identification and help with the species traits. Thanks to M.Garratt, L.Roquer, J.Bosch, P. Lhomme, E.Hulsmans, L.Fockaert for contacting the producers and finding the study sites. Many thanks to A.Anselmo, A.Danneels, A.Vandewal, B.Martinet, B.Valkenborg, E.Zambra, F.Denis, G.Ghisbain, H. Hainaut, H.Van Ryckel, M.Gérard, N.Dudermel, S.De Greef, V.Eklund and V.Nocent for their contribution to the fieldwork.

\section{Appendix A. Supporting information}

Supplementary data associated with this article can be found in the online version at doi:10.1016/j.agee.2021.107697.

\section{References}

Aizen, M.A., Garibaldi, L.A., Cunningham, S.A., Klein, A.M., 2008. Long-term globa trends in crop yield and production reveal no current pollination shortage but increasing pollinator dependency. Curr. Biol. 18, 1572-1575. https://doi.org/ 10.1016/j.cub.2008.08.066.

Alignier, A., Solé-Senan, X.O., Robleño, I., Baraibar, B., Fahrig, L., Giralt, D., Gross, N., Martin, J.L., Recasens, J., Sirami, C., Siriwardena, G., Bosem Baillod, A., Bertrand, C., Carrié, R., Hass, A., Henckel, L., Miguet, P., Badenhausser, I., Baudry, J., Bota, G., Bretagnolle, V., Brotons, L., Burel, F., Calatayud, F., Clough, Y., Georges, R., Gibon, A., Girard, J., Lindsay, K., Minano, J., Mitchell, S., Patry, N., Poulin, B., Tscharntke, T., Vialatte, A., Violle, C., Yaverscovski, N., Batáry, P., 2020. Configurational crop heterogeneity increases within-field plant diversity. J. Appl. Ecol. 57, 654-663. https://doi.org/10.1111/1365-2664.13585.

Arnold, S.E.J., Elisante, F., Mkenda, P.A., Tembo, Y.L.B., Ndakidemi, P.A., Gurr, G.M., Darbyshire, I.A., Belmain, S.R., Stevenson, P.C., 2021. Beneficial insects are associated with botanically rich margins with trees on small farms. Sci. Rep. 11. https://doi.org/10.1038/S41598-021-94536-3.

Bänsch, S., Tscharntke, T., Ratnieks, F.L.W., Härtel, S., Westphal, C., 2020. Foraging of honey bees in agricultural landscapes with changing patterns of flower resources. Agric. Ecosyst. Environ. 291, 106792 https://doi.org/10.1016/j.agee.2019.106792.

Bates, D., Mächler, M., Bolker, B.M., Walker, S.C., 2015. Fitting linear mixed-effects models using lme4. J. Stat. Softw. 67, 1-48. https://doi.org/10.18637/jss.v067.i01.

Birkhofer, K., Andersson, G.K.S., Bengtsson, J., Bommarco, R., Dänhardt, J., Ekbom, B., Ekroos, J., Hahn, T., Hedlund, K., Jönsson, A.M., Lindborg, R., Olsson, O., Rader, R., Rusch, A., Stjernman, M., Williams, A., Smith, H.G., 2018. Relationships between multiple biodiversity components and ecosystem services along a landscape complexity gradient. Biol. Conserv. 218, 247-253. https://doi.org/10.1016/j. biocon.2017.12.027.

Blitzer, E.J., Gibbs, J., Park, M.G., Danforth, B.N., 2016. Pollination services for apple are dependent on diverse wild bee communities. Agric. Ecosyst. Environ. 221, 1-7. https://doi.org/10.1016/j.agee.2016.01.004. 
Boyle, E.E., Adamowicz, S.J., 2015. Community phylogenetics: assessing tree reconstruction methods and the utility of DNA barcodes. PLoS One 10, e0126662. https://doi.org/10.1371/journal.pone.0126662.

Breeze, T.D., Bailey, A.P., Balcombe, K.G., Potts, S.G., 2011. Pollination services in the UK: how important are honeybees? Agric. Ecosyst. Environ. 142, 137-143. https:// doi.org/10.1016/j.agee.2011.03.020.

Brittain, C., Williams, N., Kremen, C., Klein, A.M., 2013. Synergistic effects of non-Apis bees and honey bees for pollination services. Proc. R. Soc. B Biol. Sci. 280, 1-7. $\langle$ https://doi.org/10.1098/rspb.2012.2767〉.

Buchhorn, M., Lesiv, M., Tsendbazar, N.E., Herold, M., Bertels, L., Smets, B., 2020. Copernicus global land cover layers-collection 2. Remote Sens. 12. https://doi.org/ $10.3390 / \mathrm{rs} 12061044$.

Campbell, A.J., Wilby, A., Sutton, P., Wäckers, F.L., 2017. Do sown flower strips boost wild pollinator abundance and pollination services in a spring-flowering crop? A case study from UK cider apple orchards. Agric. Ecosyst. Environ. 239, 20-29. https://doi.org/10.1016/j.agee.2017.01.005.

Cardoso, P., Rigal, F., Carvalho, J.C., 2015. BAT - biodiversity assessment tools, an R package for the measurement and estimation of alpha and beta taxon, phylogenetic and functional diversity. Methods Ecol. Evol. 6, 232-236. https://doi.org/10.1111/ 2041-210X.12310.

Cariveau, D.P., Nayak, G.K., Bartomeus, I., Zientek, J., Ascher, J.S., Gibbs, J., Winfree, R., 2016. The allometry of bee proboscis length and its uses in ecology. PLoS One 11, e0151482. https://doi.org/10.1371/journal.pone.0151482.

Carreck, N., 2016. Field guide to the bees of Great Britain and Ireland, By Stephen Falk. Illustrated by Richard Lewington. Bee World 93, 85. https://doi.org/10.1080/ $0005772 x .2016 .1257474$.

Droege, S., Tepedino, V.J., Lebuhn, G., Link, W., Minckley, R.L., Chen, Q., Conrad, C., 2010. Spatial patterns of bee captures in North American bowl trapping surveys. Insect Conserv. Divers. 3, 15-23. https://doi.org/10.1111/j.1752-4598.2009.00074. $\mathrm{X}$.

FAOSTAT, 2020. FAOSTAT (WWW Document). 〈http://www.fao.org/faostat/en /\#home. . (Accessed 19 June 2020).

Fontaine, C., Dajoz, I., Meriguet, J., Loreau, M., 2005. Functional diversity of plant-pollinator interaction webs enhances the persistence of plant communities. PLoS Biol. 4, e1 https://doi.org/10.1371/JOURNAL.PBIO.0040001.

Forrest, J.R.K., Thorp, R.W., Kremen, C., Williams, N.M., 2015. Contrasting patterns in species and functional-trait diversity of bees in an agricultural landscape. J. Appl. Ecol. 52, 706-715. https://doi.org/10.1111/1365-2664.12433.

Fox, J., Weisberg, S., 2014. An R companion to applied regression. Robust. Regres. 1-17.

Garibaldi, L.A., Carvalheiro, L.G., Vaissière, B.E., Gemmill-Herren, B., Hipólito, J., Freitas, B.M., Ngo, H.T., Azzu, N., Sáez, A., Åström, J., An, J., Blochtein, B., Buchori, D., Chamorro García, F.J., Da Silva, F.O., Devkota, K., De Fátima Ribeiro, M., Freitas, L., Gaglianone, M.C., Goss, M., Irshad, M., Kasina, M., Pacheco Filho, A.J.S., Piedade Kiill, L.H., Kwapong, P., Parra, G.N., Pires, C., Pires, V., Rawal, R.S., Rizali, A., Saraiva, A.M., Veldtman, R., Viana, B.F., Witter, S., Zhang, H., 2016. Mutually beneficial pollinator diversity and crop yield outcomes in small and large farms. Science 351, 388-391. https://doi.org/10.1126/science.aac7287.

Garibaldi, L.A., Steffan-Dewenter, I., Winfree, R., Aizen, M.A., Bommarco, R., Cunningham, S.A., Kremen, C., Carvalheiro, L.G., Harder, L.D., Afik, O., Bartomeus, I., Benjamin, F., Boreux, V., Cariveau, D., Chacoff, N.P., Dudenhöffer, J. H., Freitas, B.M., Ghazoul, J., Greenleaf, S., Hipólito, J., Holzschuh, A., Howlett, B., Isaacs, R., Javorek, S.K., Kennedy, C.M., Krewenka, K.M., Krishnan, S., Mandelik, Y., Mayfield, M.M., Motzke, I., Munyuli, T., Nault, B.A., Otieno, M., Petersen, J., Pisanty, G., Potts, S.G., Rader, R., Ricketts, T.H., Rundlöf, M., Seymour, C.L., Schüepp, C., Szentgyörgyi, H., Taki, H., Tscharntke, T., Vergara, C.H., Viana, B.F., Wanger, T.C., Westphal, C., Williams, N., Klein, A.M., 2013. Wild pollinators enhance fruit set of crops regardless of honey bee abundance. Science 340 , 1608-1611. https://doi.org/10.1126/science.1230200.

Gathmann, A., Tscharntke, T., 2002. Foraging ranges of solitary bees. J. Anim. Ecol. 71, 757-764. https://doi.org/10.1046/j.1365-2656.2002.00641.x.

Geslin, B., Gauzens, B., Baude, M., Dajoz, I., Fontaine, C., Henry, M., Ropars, L., Rollin, O., Thébault, E., Vereecken, N.J., 2017. Massively introduced managed species and their consequences for plant-pollinator interactions. In: Advances in Ecological Research. Academic Press Inc, pp. 147-199. https://doi.org/10.1016/bs. aecr.2016.10.007.

Geslin, B., Gauzens, B., Thébault, E., Dajoz, I., 2013. Plant pollinator networks along a gradient of urbanisation. PLoS One 8, e63421. https://doi.org/10.1371/journal. pone. 0063421.

Gotelli, N.J., Colwell, R.K., 2001. Quantifying biodiversity: procedures and pitfalls in the measurement and comparison of species richness. Ecol. Lett. 4, 379-391. https:// doi.org/10.1046/j.1461-0248.2001.00230.x.

Grab, H., Branstetter, M.G., Amon, N., Urban-Mead, K.R., Park, M.G., Gibbs, J., Blitzer, E. J., Poveda, K., Loeb, G., Danforth, B.N., 2019. Agriculturally dominated landscapes reduce bee phylogenetic diversity and pollination services. Science 363, 282-284. https://doi.org/10.1126/science.aat6016.

Graystock, P., Ng, W.H., Parks, K., Tripodi, A.D., Muñiz, P.A., Fersch, A.A., Myers, C.R. McFrederick, Q.S., McArt, S.H., 2020. Dominant bee species and floral abundance drive parasite temporal dynamics in plant-pollinator communities. Nat. Ecol. Evol. 4, 1358-1367. https://doi.org/10.1038/s41559-020-1247-x.

Guala, G., Döring, M., 2021. Integrated taxonomic information system (ITIS) (WWW Document). Choice Rev. Online. 〈https://doi.org/10.5860/choice.49-6871〉.

Hesselbarth, M.H.K., Sciaini, M., With, K.A., Wiegand, K., Nowosad, J., 2019. Landscapemetrics: an open-source R tool to calculate landscape metrics. Ecography 42, 1648-1657. https://doi.org/10.1111/ecog.04617.

Hill, S., 1985. Redesigning the food system for sustainability. Alternatives 12, 32-36.
Hillebrand, H., Bennett, D.M., Cadotte, M.W., 2008. Consequences of dominance: a review of evenness effects on local and regional ecosystem processes. Ecology 89, 1510-1520. https://doi.org/10.1890/07-1053.1.

Hoehn, P., Tscharntke, T., Tylianakis, J.M., Steffan-Dewenter, I., 2008. Functional group diversity of bee pollinators increases crop yield. Proc. R. Soc. B Biol. Sci., 275, 2283-2291. 〈https://doi.org/10.1098/rspb.2008.0405〉.

Holzschuh, A., Steffan-Dewenter, I., Tscharntke, T., 2008. Agricultural landscapes with organic crops support higher pollinator diversity. Oikos 117, 354-361. https://doi. org/10.1111/j.2007.0030-1299.16303.x.

Hristov, P., Shumkova, R., Palova, N., Neov, B., 2020. Factors associated with honey bee colony losses: a mini-review. Vet. Sci. 7, 1-16. https://doi.org/10.3390/ vetsci7040166.

Hung, K.L.J., Kingston, J.M., Lee, A., Holway, D.A., Kohn, J.R., 2019. Non-native honey bees disproportionately dominate the most abundant floral resources in a biodiversity hotspot. Proc. R. Soc. B Biol. Sci., 286. 〈https://doi.org/10.1098/rspb. 2018.2901).

Isbell, F., Adler, P.R., Eisenhauer, N., Fornara, D., Kimmel, K., Kremen, C., Letourneau, D. K., Liebman, M., Polley, H.W., Quijas, S., Scherer-Lorenzen, M., 2017. Benefits of increasing plant diversity in sustainable agroecosystems. J. Ecol. 105, 871-879. https://doi.org/10.1111/1365-2745.12789.

Joshi, N.K., Leslie, T., Rajotte, E.G., Biddinger, D.J., 2020. Environmental impacts of reduced-risk and conventional pesticide programs differ in commercial apple orchards, but similarly influence pollinator community. Chemosphere 240, 124926. https://doi.org/10.1016/j.chemosphere.2019.124926.

Joshi, N.K., Otieno, M., Rajotte, E.G., Fleischer, S.J., Biddinger, D.J., 2016. Proximity to woodland and landscape structure drives pollinator visitation in apple orchard ecosystem. Front. Ecol. Evol. 4, 1-9. https://doi.org/10.3389/fevo.2016.00038.

Kirchmann, H., Kätterer, T., Bergström, L., Börjesson, G., Bolinder, M.A., 2016. Flaws and criteria for design and evaluation of comparative organic and conventional cropping systems. F. Crop. Res. 186, 99-106. https://doi.org/10.1016/J. FCR.2015.11.006.

Klein, A.M., Vaissière, B.E., Cane, J.H., Steffan-Dewenter, I., Cunningham, S.A., Kremen, C., Tscharntke, T., 2007. Importance of pollinators in changing landscapes for world crops. Proc. R. Soc. B Biol. Sci., 274, 303-313. 〈https://doi.org/10.1098/rspb.2006. $3721\rangle$.

Krishna, S., Keasar, T., 2018. Morphological complexity as a floral signal: from perception by insect pollinators to co-evolutionary implications. Int. J. Mol. Sci. 19. https://doi.org/10.3390/IJMS19061681.

Laliberté, E., Legendre, P., Shipley, B., 2015. FD: measuring functional diversity from multiple traits, and other tools for functional ecology. R. Packag. Version 1, 0-12.

Lindström, S.A.M., Herbertsson, L., Rundlöf, M., Bommarco, R., Smith, H.G., 2016. Experimental evidence that honeybees depress wild insect densities in a flowering crop. Proc. R. Soc. B Biol. Sci., 283, 20161641. 〈https://doi.org/10.1098/rspb.2016. $1641\rangle$.

Mallinger, R.E., Gaines-Day, H.R., Gratton, C., 2017. Do managed bees have negative effects on wild bees? A systematic review of the literature. PLoS One 12, e0189268. https://doi.org/10.1371/journal.pone.0189268.

Mallinger, R.E., Gratton, C., 2015. Species richness of wild bees, but not the use of managed honeybees, increases fruit set of a pollinator-dependent crop. J. Appl. Ecol. 52, 323-330. https://doi.org/10.1111/1365-2664.12377.

Marini, L., Quaranta, M., Fontana, P., Biesmeijer, J.C., Bommarco, R., 2012. Landscape context and elevation affect pollinator communities in intensive apple orchards. Basic Appl. Ecol. 13, 681-689. https://doi.org/10.1016/j.baae.2012.09.003.

Marliac, G., Penvern, S., Barbier, J.M., Lescourret, F., Capowiez, Y., 2015. Impact of crop protection strategies on natural enemies in organic apple production. Agron. Sustain. Dev. 35, 803-813. https://doi.org/10.1007/s13593-015-0282-5.

Martins, K.T., Gonzalez, A., Lechowicz, M.J., 2015. Pollination services are mediated by bee functional diversity and landscape context. Agric. Ecosyst. Environ. 200, 12-20. https://doi.org/10.1016/j.agee.2014.10.018.

Mateos-Fierro, Z., Fountain, M.T., Garratt, M.P.D., Ashbrook, K., Westbury, D.B., 2021. Active management of wildflower strips in commercial sweet cherry orchards enhances natural enemies and pest regulation services. Agric. Ecosyst. Environ. 317, 107485 https://doi.org/10.1016/j.agee.2021.107485.

McKerchar, M., Potts, S.G., Fountain, M.T., Garratt, M.P.D., Westbury, D.B., 2020. The potential for wildflower interventions to enhance natural enemies and pollinators in commercial apple orchards is limited by other management practices. Agric. Ecosyst. Environ. 301, 107034 https://doi.org/10.1016/J.AGEE.2020.107034.

Merfield, C., Moller, H., Manhire, J., Rosin, C., Norton, S., Carey, P., Hunt, L., Reid, J., Fairweather, J., Benge, J., Quellec, I., Le, Campbell, H., Lucock, D., Saunders, C., MacLeod, C., Barber, A., McCarthy, A., 2015. Are organic standards sufficient to ensure sustainable agriculture? Lessons from New Zealand's ARGOS and sustainability dashboard projects. Sustain. Agric. Res. 4, 158. https://doi.org/ 10.5539/sar.v4n3p158.

Mouchet, M.A., Villéger, S., Mason, N.W.H., Mouillot, D., 2010. Functional diversity measures: an overview of their redundancy and their ability to discriminate community assembly rules. Funct. Ecol. 24, 867-876. https://doi.org/10.1111/ j.1365-2435.2010.01695.x.

Mouillot, D., Graham, N.A.J., Villéger, S., Mason, N.W.H., Bellwood, D.R., 2013. A functional approach reveals community responses to disturbances. Trends Ecol. Evol. 28, 167-177. https://doi.org/10.1016/j.tree.2012.10.004.

Nicholls, C.I., Altieri, M.A., 2013. Plant biodiversity enhances bees and other insect pollinators in agroecosystems. A review. Agron. Sustain. Dev. 33, 257-274. https:// doi.org/10.1007/s13593-012-0092-y.

Nielsen, A., Steffan-Dewenter, I., Westphal, C., Messinger, O., Potts, S.G., Roberts, S.P.M., Settele, J., Szentgyörgyi, H., Vaissière, B.E., Vaitis, M., Woyciechowski, M., Bazos, I., Biesmeijer, J.C., Bommarco, R., Kunin, W.E., Tscheulin, T., Lamborn, E., 
Petanidou, T., 2011. Assessing bee species richness in two Mediterranean communities: importance of habitat type and sampling techniques. Ecol. Res. 26, 969-983. https://doi.org/10.1007/s11284-011-0852-1.

Nieto, A., Roberts, S.P.M., Kemp, J., Rasmont, P., Kuhlmann, M., García Criado, M., Biesmeijer, J.C., Bogusch, P., Dathe, H.H., De la Rúa, P., De Meulemeester, T., Dehon, M., Dewulf, A., Ortiz-Sánchez, F.J., Lhomme, P., Pauly, A., Potts, S.G., Praz, C., Q., Window, J., Michez, D., 2014. European Red List of Bees. IUCN Global Species Programme. https://doi.org/10.2779/77003.

Normandin, É., Vereecken, N.J., Buddle, C.M., Fournier, V., 2017. Taxonomic and functional trait diversity of wild bees in different urban settings. PeerJ 5, e3051. https://doi.org/10.7717/peerj.3051.

Nunes-Silva, P., Witter, S., da Rosa, J.M., Halinski, R., Schlemmer, L.M., Arioli, C.J., Ramos, J.D., Botton, M., Blochtein, B., 2020. Diversity of floral visitors in apple orchards: influence on fruit characteristics depends on apple cultivar. Neotrop. Entomol. 49, 511-524. https://doi.org/10.1007/s13744-020-00762-1.

Odanaka, K.A., Rehan, S.M., 2019. Impact indicators: effects of land use management on functional trait and phylogenetic diversity of wild bees. Agric. Ecosyst. Environ. 286. https://doi.org/10.1016/j.agee.2019.106663.

Ollerton, J., Winfree, R., Tarrant, S., 2011. How many flowering plants are pollinated by animals? Oikos 120, 321-326. https://doi.org/10.1111/j.1600-0706.2010.18644.x.

Orpet, R.J., Jones, V.P., Beers, E.H., Reganold, J.P., Goldberger, J.R., Crowder, D.W., 2020. Perceptions and outcomes of conventional vs. organic apple orchard management. Agric. Ecosyst. Environ. 289, 106723 https://doi.org/10.1016/j. agee.2019.106723.

Paradis, E., Schliep, K., 2019. Ape 5.0: an environment for modern phylogenetics and evolutionary analyses in R. Bioinformatics 35, 526-528. https://doi.org/10.1093/ bioinformatics/bty633.

Pardo, A., Borges, P.A.V., 2020. Worldwide importance of insect pollination in apple orchards: a review. Agric. Ecosyst. Environ. 293, 106839 https://doi.org/10.1016/j agee.2020.106839.

Park, M.G., Joshi, N.K., Rajotte, E.G., Biddinger, D.J., Losey, J.E., Danforth, B.N., 2020 Apple grower pollination practices and perceptions of alternative pollinators in New York and Pennsylvania. Renew. Agric. Food Syst. 35, 1-14. https://doi.org/ 10.1017/S1742170518000145.

Penvern, S., Fernique, S., Cardona, A., Herz, A., Ahrenfeldt, E., Dufils, A., Jamar, L., Korsgaard, M., Kruczyńska, D., Matray, S., Ozolina-Pole, L., Porcel, M., Ralle, B., Steinemann, B., Świergiel, W., Tasin, M., Telfser, J., Warlop, F., Sigsgaard, L., 2019. Farmers' management of functional biodiversity goes beyond pest management in organic European apple orchards. Agric. Ecosyst. Environ. 284, 106555 https://doi. org /10.1016/j.agee.2019.05.014.

Penvern, S., Simon, S., Bellon, S., Alaphilippe, A., Lateur, M., Lauri, P.-E., Dapena, E., Jamar, L., Hemptinne, J.-L., Warlop, F., 2012. Sustainable Orchards' Redesign: at the Crossroads of Multiple Approaches, 13.

Pérez-Méndez, N., Andersson, G.K.S., Requier, F., Hipólito, J., Aizen, M.A., Morales, C.L., García, N., Gennari, G.P., Garibaldi, L.A., 2020. The economic cost of losing native pollinator species for orchard production. J. Appl. Ecol. 57, 599-608. https://doi. org/10.1111/1365-2664.13561.

Petchey, O.L., Gaston, K.J., 2006. Functional diversity: back to basics and looking forward. Ecol. Lett. 9, 741-758. https://doi.org/10.1111/j.1461-0248.2006.00924. $\mathrm{x}$.

Petchey, O.L., Gaston, K.J., 2007. Dendrograms and measuring functional diversity. Oikos 116, 1422-1426. https://doi.org/10.1111/j.0030-1299.2007.15894.x.

Porcel, M., Andersson, G.K.S., Pålsson, J., Tasin, M., 2018. Organic management in apple orchards: Higher impacts on biological control than on pollination. J. Appl. Ecol. 55, 2779-2789. https://doi.org/10.1111/1365-2664.13247.

Potts, S., Biesmeijer, K., Bommarco, R., Breeze, T., Carvalheiro, L., Franzen, M., González-Varo, J.P., Holzschuh, A., Kleijn, D., Klein, A.-M., Kunin, B., Lecocq, T., Lundin,O., Michez, D., Neumann, P., Nieto, A., Penev, L., Rasmont, P., Ratamäki, O. Riedinger, V., Roberts, S.P.M., Rundlöf, M., Scheper, J., Sorensen, P., SteffanDewenter, I., Stoev, P., Vila, M., Schweiger, O., 2015. Status andtrends of European pollinators. Key findings of the STEP project.

Potts, S.G., Biesmeijer, J.C., Kremen, C., Neumann, P., Schweiger, O., Kunin, W.E., 2010 Global pollinator declines: trends, impacts and drivers. Trends Ecol. Evol. 25, 345-353. https://doi.org/10.1016/j.tree.2010.01.007.

Prendergast, K.S., Leclercq, N., Vereecken, N.J., 2021. Honey bees (Hymenoptera: Apidae) outnumber native bees in Tasmanian apple orchards: perspectives for balancing crop production and native bee conservation. Austral Entomol. 60, 422-435. https://doi.org/10.1111/aen.12521.

Prendergast, K.S., Ollerton, J., 2021. Plant-pollinator networks in Australian urban bushland remnants are not structurally equivalent to those in residential gardens. Urban Ecosyst. 24, 973-987. https://doi.org/10.1007/s11252-020-01089-w.

Pretty, J., 2020. New opportunities for the redesign of agricultural and food systems. Agric. Hum. Values 37, 629-630. https://doi.org/10.1007/s10460-020-10056-2.

R Core Team, 2013. A language and environment for statistical computing. R. Found. Stat. Comput. 2. 〈https://www.R-project.org .

Rader, R., Howlett, B.G., Cunningham, S.A., Westcott, D.A., Newstrom-Lloyd, L.E., Walker, M.K., Teulon, D.A.J., Edwards, W., 2009. Alternative pollinator taxa are equally efficient but not as effective as the honeybee in a mass flowering crop. J. Appl. Ecol. 46, 1080-1087. https://doi.org/10.1111/j.1365-2664.2009.01700.x.

Raderschall, C.A., Bommarco, R., Lindström, S.A.M., Lundin, O., 2021. Landscape crop diversity and semi-natural habitat affect crop pollinators, pollination benefit and yield. Agric. Ecosyst. Environ. 306. https://doi.org/10.1016/j.agee.2020.107189.

Radzevičiūtè, R., Theodorou, P., Schlegel, M., Paxton, R.J., 2021. A two-part modelling approach reveals a positive effect of pollinator biodiversity in boosting the pollination of apple flowers. Agric. Ecosyst. Environ. 306, 107197 https://doi.org/ 10.1016/j.agee.2020.107197.

Ramírez, F., Davenport, T.L., 2013. Apple pollination: a review. Sci. Hortic. 162, 188-203. https://doi.org/10.1016/j.scienta.2013.08.007.

Reganold, J.P., Glover, J.D., Andrews, P.K., Hinman, H.R., 2001. Sustainability of three apple production systems. Nature, 20014106831 410, 926-930. 〈https://doi. org/10.1038/35073574).

Rodríguez-Gironés, M.A., Santamaría, L., 2006. Models of optimal foraging and resource partitioning: deep corollas for long tongues. Behav. Ecol. 17, 905-910. https://doi. org/10.1093/BEHECO/ARL024.

Ropars, L., Affre, L., Schurr, L., Flacher, F., Genoud, D., Mutillod, C., Geslin, B., 2020. Land cover composition, local plant community composition and honeybee colony density affect wild bee species assemblages in a Mediterranean biodiversity hot-spot. Acta Oecol. 104, 103546 https://doi.org/10.1016/j.actao.2020.103546.

Ropars, L., Dajoz, I., Fontaine, C., Muratet, A., Geslin, B., 2019. Wild pollinator activity negatively related to honey bee colony densities in urban context. PLoS One 14 https://doi.org/10.1371/journal.pone.0222316.

Roulston, T.H., Smith, S.A., Brewster, A.L., 2007. Short communication: a comparison of pan trap and intensive net sampling techniques for documenting a bee (Hymenoptera: Apiformes) fauna. J. Kans. Entomol. Soc. 80, 179-181. https://doi. org/10.2317/0022-8567(2007)80[179:ACOPTA]2.0.CO;2.

Rousset, F., Ferdy, J.B., 2014. Testing environmental and genetic effects in the presence of spatial autocorrelation. Ecography 37, 781-790. https://doi.org/10.1111/ ecog.00566.

Rundlöf, M., Smith, H.G., Birkhofer, K., 2016. Effects of Organic Farming on Biodiversity. In: ELS. John Wiley \& Sons Ltd, pp. 1-7. https://doi.org/10.1002/9780470015902. a0026342.

Sheffield, C.S., Ngo, H.T., Azzu, N., 2016. A Manual on Apple Pollination.

Shennan, C., Krupnik, T.J., Baird, G., Cohen, H., Forbush, K., Lovell, R.J., Olimpi, E.M., 2017. Organic and conventional agriculture: a useful framing? Annu. Rev. Environ. Resour. 42, 317-346. https://doi.org/10.1146/annurev-environ-110615-085750.

Simon, S., Brun, L., Guinaudeau, J., Sauphanor, B., 2011. Pesticide use in current and innovative apple orchard systems. Agron. Sustain. Dev. 31, 541-555. https://doi. org/10.1007/s13593-011-0003-7.

Stefan, V., 2019. Geobuffer: Geodesic Buffer Around Points (Long, Lat) Using Metric Radius.

Theodorou, P., Radzevičiūtè, R., Lentendu, G., Kahnt, B., Husemann, M., Bleidorn, C., Settele, J., Schweiger, O., Grosse, I., Wubet, T., Murray, T.E., Paxton, R.J., 2020. Urban areas as hotspots for bees and pollination but not a panacea for all insects. Nat. Commun. 11, 576. https://doi.org/10.1038/s41467-020-14496-6.

Tscharntke, T., Grass, I., Wanger, T.C., Westphal, C., Batáry, P., 2021. Beyond organic farming - harnessing biodiversity-friendly landscapes. Trends Ecol. Evol. 36, 919-930. https://doi.org/10.1016/j.tree.2021.06.010.

Valido, A., Rodríguez-Rodríguez, M.C., Jordano, P., 2019. Honeybees disrupt the structure and functionality of plant-pollinator networks. Sci. Rep. 9. https://doi.org/ 10.1038/s41598-019-41271-5.

Vereecken, N.J., 2017. Découvrir et Protéger Nos Abeilles Sauvages, Glénat. ed.

Vereecken, N.J., Weekers, T., Leclercq, N., De Greef, S., Hainaut, H., Molenberg, J.-M., Martin, Y., Janssens, X., Noël, G., Pauly, A., Roberts, S.P.M., Marshall, L., 2020. Insect biomass is not a consistent proxy for biodiversity metrics in wild bees. Ecol. Indic., 107132 https://doi.org/10.1016/j.ecolind.2020.107132.

Wagner, D.L., 2020. Insect declines in the anthropocene. Annu. Rev. Entomol. 65, 457-480. https://doi.org/10.1146/annurev-ento-011019-025151.

Westphal, C., Bommarco, R., Carré, G., Lamborn, E., Morison, N., Petanidou, T., Potts, S. G., Roberts, S.P.M., Szentgyörgyi, H., Tscheulin, T., Vaissière, B.E., Woyciechowski, M., Biesmeuer, J.C., Kunin, W.E., Settele, J., Steffan-Dewenter, I., 2008. Measuring bee diversity in different European habitats and biogeographical regions. Ecol. Monogr. 78, 653-671. https://doi.org/10.1890/07-1292.1.

Wignall, V.R., Brolly, M., Uthoff, C., Norton, K.E., Chipperfield, H.M., Balfour, N.J., Ratnieks, F.L.W., 2020. Exploitative competition and displacement mediated by eusocial bees: experimental evidence in a wild pollinator community. Behav. Ecol. Sociobiol. 74, 1-15. https://doi.org/10.1007/s00265-020-02924-y.

Willer, H., Travnicek, J., Meier, C., Schlatter, B., 2021.The World of Organic Agriculture, 2021.

Wojcik, V.A., Morandin, L.A., Davies Adams, L., Rourke, K.E., 2018. Floral resource competition between honey bees and wild bees: is there clear evidence and can we guide management and conservation? Environ. Entomol. 47, 822-833. https://doi. org/10.1093/ee/nvy077.

Wood, T.J., Michez, D., Paxton, R.J., Drossart, M., Neumann, P., Gérard, M., Vanderplanck, M., Barraud, A., Martinet, B., Leclercq, N., Vereecken, N.J., 2020. Managed honey bees as a radar for wild bee decline? Apidologie 1-17. https://doi. org /10.1007/s13592-020-00788-9.

Woodcock, B.A., Garratt, M.P.D., Powney, G.D., Shaw, R.F., Osborne, J.L., Soroka, J., Lindström, S.A.M., Stanley, D., Ouvrard, P., Edwards, M.E., Jauker, F., McCracken, M.E., Zou, Y., Potts, S.G., Rundlöf, M., Noriega, J.A., Greenop, A., Smith, H.G., Bommarco, R., van der Werf, W., Stout, J.C., Steffan-Dewenter, I., Morandin, L., Bullock, J.M., Pywell, R.F., 2019. Meta-analysis reveals that pollinator functional diversity and abundance enhance crop pollination and yield. Nat. Commun. 10, 1-10. https://doi.org/10.1038/s41467-019-09393-6.

Zurbuchen, A., Landert, L., Klaiber, J., Müller, A., Hein, S., Dorn, S., 2010. Maximum foraging ranges in solitary bees: only few individuals have the capability to cover long foraging distances. Biol. Conserv. 143, 669-676. https://doi.org/10.1016/j. biocon.2009.12.003. 